\title{
Criteria of waxes' performance in the consolidation of steatites (soapstone) in heritage buildings
}

\author{
L. P. da Guia ${ }^{1}$ \& A. L. T. S. da Motta ${ }^{2}$ \\ ${ }^{I}$ Centro Federal de Educação Tecnológica de Minas Gerais - \\ CEFET-MG, Brazil \\ ${ }^{2}$ Programa de Pós-Graduação em Engenharia Civil \\ da Universidade Federal Fluminense, Brazil
}

\begin{abstract}
The present work investigates the use of consolidants in stone material of integrated built heritage undergoing the action of some acids derived from pollutant air gases on the steatites (soapstone) of architectural works as well as the description of the correlated chemical reactions. It is proposed to examine these atmospheric pollutants, highlighting the $\mathrm{SO}_{2}$ and $\mathrm{NO}_{2}$ gases and their respective acids. If these gases from fossil fuel burning act decisively in the stone material and one can slow down and/or prevent degradation through the use of consolidant chemicals with certain characteristics by means of technical standards, e.g. the quality of the consolidation, depth of penetration, porosity, consolidating compatibility with rock, final appearance and safety during application. Initially, the basic characteristics and chemical composition of the stone material were studied as well as its occurrence in equity work properties. This research addresses the consolidation of steatites (soapstone) by the use of wax for the control of degradation in stone material heritage.

Keywords: air pollutants, monuments, built heritage, building stones, conservation and deterioration.
\end{abstract}

\section{Introduction}

Steatites (soapstone) are very important rocks in heritage projects in Brazil. The historical buildings of the Baroque period in the cities of Ouro Preto, Mariana and 
Congonhas do Campo in Minas Gerais are numerous. They are part of the Cinturão de Rochas Verdes (Rio das Velhas) [1]. A steatite is considered to be a solid rock, consisting mainly of the mineral named talc [2, 3], $\mathrm{Mg}_{3} \mathrm{Si}_{4} \mathrm{O}_{10}(\mathrm{OH})_{2}$. It also contains other minerals; however, the proportions of carbonate can be greater than $20 \%$. It is a rock of low hardness. Talc was generated in hydrothermal alteration minerals, magnesia and metamorphism on magnesia limestone or ultrabasic rocks [4]. As for color, it is possible to say that steatites are gray to graygreen, varying in shade according to the distribution of the constituent minerals. When weathered they are brownish due to iron oxides and hydroxides and contain macroscopic pores and cavities resulting from leaching porphyroblasts, carbonates and sulphides. One can observe the existence of millimetric to centimetric cracks [1]. What favours the use of this rock in heritage works is its easy handling and parts with detail finishing. However, such use also causes degradation of these parts for the great exposure of the constituent elements to the weather. The degradation of pyrite and carbonates will expose and promote changes in other constituent minerals. It is not unusual to observe several works of heritage made from steatite with severe damage by acid deposition.

\section{Chemical degradation}

Chemical degradation reactions continuously occur and are processed on the surfaces of the crystals of the mineral. Thus, some rocks dissolve and others are modified by reacting with water and other dissolved components of the atmosphere, forming new compounds. Currently, the mineral dissolution heritage of rocks is closely linked to air pollution and acid deposition [5]. For example, in today's urban centres, it is not uncommon for the total or partial leaching of pyrite (iron disulphide, $\mathrm{FeS}_{2}$ ) present in steatites. Many minerals present in rocks and buildings on the Earth's surface are thermodynamically unstable. The reaction of $\mathrm{H}^{+}$ions on the rock components leads to their degradation and formation of byproducts. The action of acids usually cause the displacement of metal cations and silica dissolved from the base minerals. The mineral dissolution reaction rates depend on the following factors [6]: the amount of liquid water and contact time on mineral available on the surfaces; the solubility of the mineral present in the rock; the $\mathrm{pH}$ of the aqueous solution in contact with the surface of the mineral. The main source of water in liquid form, to which historic buildings are subject, stems from rainfall. The damage caused by the dissolution reactions of minerals often present a distinct pattern after exposure to direct rainfall and to the surface water flow. Many minerals that form rocks have a reduced solubility in water contact. In historic buildings, the amount of rain water infiltration due to contact time and over time are sufficiently necessary for the mineral dissolution reactions could cause significant damage. The carbonate minerals have high solubility in the presence of water, when compared with feldspars, followed by clay minerals and quartz. As a rule, the solubility increases with decreasing silica content and increased content of calcium and magnesium. The solubility of minerals from rocks also increases with decreasing $\mathrm{pH}$ in acidic solutions [5]. Examples are biotite, chlorite and kaolinite. 


\section{Atmospheric greenhouse gases}

The following air pollutants, considered by the United States Environmental Protection Agency [7], were selected for this study: sulphur dioxide $\left(\mathrm{SO}_{2}\right)$ and nitrogen oxides (NOx). The reason for the choice of these parameters as air quality indicators is linked to their greater frequency of occurrence and of the adverse effects they cause and the fact that they are used universally by pollution control agencies. These pollutants have great impact on the environment and the rocks. When determining the concentration of a pollutant in the atmosphere, CETESB [8] measures the degree of exposure of objects (for works of historical heritage). The final result of the release process of this pollutant in the atmosphere takes into account its emission sources and their interactions in the atmosphere, from the physical point of view (dilution) and chemical (chemical reactions).

\subsection{Sulphur dioxide $\left(\mathrm{SO}_{2}\right)$}

Sulphur dioxide $\left(\mathrm{SO}_{2}\right)$ is part of a group of highly reactive gases known as oxides of sulphur. Combustion processes are responsible for over $74 \%$ of all issued $\mathrm{SO}_{2}$ [8]. Many researchers argue that sulphur dioxide levels in some cities have been reduced to the point where it is not essential to the degradation of stone material, but this affirmation is questionable. Thus Sharma and Gupta [9] stated that there may be a safe level of about $30 \mu \mathrm{g} / \mathrm{m}^{3}$ below which sulphur dioxide is not a significant problem. The Quality Standards National Air Brazil (CONAMA) [10] claim that in 24 hours the $\mathrm{SO}_{2}$ levels can reach $365 \mu \mathrm{g} / \mathrm{m}^{3}$ which leads us to believe that monitoring is absolutely necessary in order to evaluate the composition of air where the heritage property is located. For the amount of deposition, there is a consensus in the scientific community about the importance of wet and dry deposition of $\mathrm{SO}_{2}$. The question arises: what is the path that the pollutants contained in the air $\left(\mathrm{SO}_{2}\right)$ run to the surface of the stone? The possible responses are: a) dissolved in water droplets of the clouds and rain and reach the stone already in solution (called wet deposition); b) they reach the surface of the stone in the gas phase and then dissolve in the moisture already present in the stone (dry deposition). The $\mathrm{SO}_{2}$ is combined with other compounds which react with the stone material. The importance of this issue lies in the fact that a distant pollution source will be the main contributor to the wet deposition, while local sources will predominate in the dry deposition. Doehne et al. [11] show that when sulphur dioxide levels are high, the dry deposition seems to predominate on vertical surfaces; on horizontal surfaces and in rural areas, wet and dry deposition can be of comparable importance.

\subsection{Nitrogen oxides (NO}

Nitrogen dioxide $\left(\mathrm{NO}_{2}\right)$ is part of a group of highly reactive gases known as nitrogen oxides (NOx). The nitrogen oxides include nitrous acid and nitric acid. $\mathrm{NO}_{2}$ is the component of greatest interest and the indicator for the largest group of nitrogen oxides. $\mathrm{NO}_{2}$ comes from car emissions, trucks and buses, power plants and off-road equipment. Degradation of stone heritage by nitrogen oxides has 
received little importance compared with research on sulphur dioxide. The oxidation of NOx species in the presence of water vapour may result in the generation of nitric acid [12]. Nitric acid reacts with the calcareous stone, but NOx species may have little effect on the stone compared with sulphur dioxide. Mangio and Johansson [13] demonstrated that at $90 \%$ relative humidity, $\mathrm{NO}_{2}$ causes an increase of the mass of stone material consisting of calcium carbonate $\left(\mathrm{CaCO}_{3}\right)$ and hence its degradation.

\section{Waxes}

To understand the use of waxes in the consolidation of stone material, it is necessary to know the substance of the polyethene group or polyethylene (PE). Horie [14] states that polyethylene is obtained from the polymerization of ethylene gas. Two major forms are obtained: a low density polyethylene (LDPE) and a more uniform, high density polyethylene (HDPE). When the chains in PE are highly regular, they may suffer compression to yield crystals. These crystals form within the mass of amorphous polymer [14]. Waxes may be considered as the PE with low molecular weight versions. There are two main forms: a paraffin wax and microcrystalline wax. Most waxes are derived from crude oil fractionation, although some molecular weight PE too low are made to bridge the gap between waxes derived from oil and LDPE. Horie [14] states that the waxes are also found as minerals in rocks, is pure (ozokerite) or impure (Montana, ceresin). The straight chain alkanes constitute the majority (over $90 \%$ ) of paraffin waxes, here defined as the variety of straight chain wax. The microcrystalline wax is a branched compound of naphthenic molecules (paraffinic cycle) with molecules larger than paraffin waxes. Microcrystalline wax, which is the modern equivalent of paraffin wax, has the same chemical composition, but with simpler crystals than the paraffin waxes crystals. Therefore, in contrast with the brittle paraffin waxes, microcrystalline waxes have good plasticity and adhesion. They are effective in surface consolidating. Cabrera [15] said that paraffin waxes have been effective in increasing the water repellence of porous stone material. Cabrera [15] and Horie [14] state that the mixture of the two waxes (approximately $20-40 \%$ of microcrystalline wax) is more resistant to air pollution. Waxes are often used as barriers to water vapour [14]. However, paraffin waxes are degraded with time, suffering fractures and breaking the protective barrier. Clifton [16] states that polyethylene does not dissolve in solvents at room temperature, but can be heated and fused. Some solvents (tetrachloroethane, trichlorethylene, methyl cyclohexane, tetrachloromethane) also cause a significant increase in volume at ambient temperature up to $40 \%$ of the initial volume [16]. PE and waxes are inert to aqueous solutions (slow chemical deterioration caused by sulphur dioxide and nitrogen dioxide) and various organic solvents. However, they are subject to photo-oxidation, undergoing degradation, breaking of the molecular chains, embrittlement and discoloration, being a more susceptible microcrystalline wax than paraffin wax. PE and finally waxes also accumulate particulate matter (PM), which is harmful in works of equity by the appearance. The most common natural waxes used for the consolidation of stone material are beeswax and carnauba. 
Beeswax is obtained from bee hives. Other waxes are obtained from various sources, e.g. insect waxes, wax Carthaginian or Punic, Spermaceti wax obtained from the head cavity of the sperm whale oil (Physter macrocephalus L.), wax wool or lanolin extracted from the wool of sheep; stearin wax that is not found in nature. This consists of a mixture of stearic acid and a ratio of fatty acids of a similar long chain obtained from the hydrolysis of fats [17].

\section{Criteria}

The consolidating performance criteria used in the stone material is described below and, in parallel, the ASTM E2167-01 (adopted in 2008) - ASTM was used [18].

\subsection{The quality of consolidation}

The main requirement for consolidating stone material is to restore the physical and mechanical properties of the stone material decayed to an acceptable level by re-establishing the maximum possible connection between adjacent grains. The method provided in ASTM E632-82 [19], which is useful in consolidating development of the tests for the evaluation of the resulting consolidation.

\subsection{Depth of penetration}

The consolidation substance should have the ability to easily and deeply penetrate the stone material. Munnikedam [20] and the National Materials Advisory Board [22]. Clifton [16] suggests that a consolidant should penetrate to a depth such that the entire deteriorated area is solidified and bonded to the remainder of the stone material and it uniformly penetrates the pores of the stone material and does not accumulate on the surface, forming a crust, reducing thus permeability. Clifton [16] explains that this can result in an accumulation of moisture and salts below the consolidating layer. There are many factors that affect the penetration of consolidating.

\subsection{Porosity}

Porosity, pore size, and distribution can have a significant effect on the durability of a stone material. A consolidant that reduces the size of larger dimension pores, but does not close them can be useful. The consolidating should not negatively affect the pore structure of the stone material. One method that can be used to determine the effects of a consolidant in the pore size distribution is described by Clifton [16].

\subsection{Moisture transport}

Munnikendam [20] said that many consolidations may have a degraded performance because they can form a surface film that prevents the migration of liquid water through the treated stone material, but allows water vapour to pass 
through. This can lead to a situation where the water evaporates in the treated lower layer, allowing the development of salt crystals. The water absorption and permeability to water vapour in the stone materials, treated and untreated, can be measured by following the procedures, respectively to the standards: ASTM C97/C97M-09 [21] and ASTM E96/E96M-13 [22].

\subsection{Consolidating compatibility with the stone material}

Munnikedam [20] showed that the consolidating must be compatible with the stone material to form a durable joint.

\subsection{Appearance of the stone material}

Consolidating should not cause any change in the appearance of a stone material. Several methods can be used in the laboratory and in the field to measure the change in appearance of the stone material caused by consolidating. In a laboratory, the methods for evaluation of the conservation/maintenance of the stone material that can be followed and adapted are described in ASTM D153513 [24], ASTM D1729-96 [25], ASTM E2466-13 [26], and ASTM D523-08 [27]. In addition to these standards, many others are cited in the ASTM database.

\subsection{Application and safety}

During handling or application, consolidating should not pose risks to the health and safety of the applicator. If consolidating is toxic, volatile, flammable, etc., appropriate safety measures for applicators that include the use of protective clothing, goggles and respirators should be taken. All consolidating substances should be applied by experienced applicators. Environmental considerations regarding the protection of vegetation areas and water sources around or external/internal areas should also be taken into account.

\section{Discussion}

Doehne et al. [11] state that most research is focused on 'traditional' pollutants: sulphur oxides and nitrogen oxides. All of them are capable of being dissolved in water to produce an acidic solution and, thus react with calcareous materials such as limestone itself and marble. All those acids mentioned occur naturally, but pollution has greatly increased their levels and can be found in urban and rural areas. Neither can we fail to mention the particulate matter and the hydrocarbon family. The effects of acid pollutants in limestone depend on the environment where the equity is inserted. If the stone is in an exposed position to rain and wind, whenever it is regularly washed by rain, products deriving from the reaction are carried by the water, the dissolution phenomenon happens when the chemical decomposition of the rock occurs. The acid solution is gradually carried to the stone surface. However, if the stone is at a relatively sheltered position and not subjected to a continuous rinsing effect, the product of reactions can accumulate and form a dense black crust on the surface which captures the solid particles from 
the atmosphere. In particular, carbonaceous particulates the incomplete burning of fuels and metals and make the stone surface gain a blackish feature. Barros [28] said that the more porous a carbonated rock (limestone or marble) the more it is susceptible to develop the process of formation of a crust and the impregnation of carbonaceous and metallic particles. The sulphatation phenomenon is primarily responsible for the chemical degradation processes observed in the monuments built in limestone [28]. The phenomena are not completely understood: all intermediate steps between the initial rock - calcium carbonate $\left(\mathrm{CaCO}_{3}\right)$ - and the final product - the hydrated calcium sulphate $\left(\mathrm{CaSO}_{4} 2 \mathrm{H}_{2} \mathrm{O}\right)$. However, one can argue for consistent hypothesis for the rock degradation, based on atmospheric chemical reactions and rocks degradation. Fig. 1 shows, in summary, possible chemical reactions involving sulphur dioxide and stone materials. The oxidation occurs in the presence of $\mathrm{NO}_{2}$ in the oxidising atmosphere such as, for example, ozone $\left(\mathrm{O}_{3}\right)$ and hydrogen peroxide $\left(\mathrm{H}_{2} \mathrm{O}_{2}\right)$ and catalysts such as soot (carbon particles from the combustion) and smoke (cloud composed of elements of waste burning state: water, volatile organic compounds - variety of hydrocarbons, carbon and ash), as well as metal species in the atmosphere and impurities composed of metal oxides into the stone to perform the chemical reactions catalyst function.

\begin{tabular}{|c|c|c|c|c|}
\hline & & $\begin{array}{l}\text { ur oxide } \\
\text { water. } \\
\mathrm{O}_{2}(\mathrm{aq})\end{array}$ & & \\
\hline $\begin{array}{r}\text { Oxidation in } \mathrm{t} \\
\text { As the sulfur dioxide ga } \\
\text { droplets } \mathrm{ff} \\
\mathrm{SO}_{2}(\mathrm{~g})+ \\
\text { Substances }\end{array}$ & $\begin{array}{l}\text { se (Oxidized in } \\
\text { uble, it can be ir } \\
\text { ud, forming sul } \\
\mathrm{SO}_{3}(\mathrm{aq}) \text { - sulph } \\
\text { the atmosphe }\end{array}$ & $\begin{array}{l}\text { ir). } \\
\text { tio the water }\end{array}$ & $\begin{array}{l}\text { Fixed by wet deposition: } \\
\text { this comes from the sulfur } \\
\text { dioxide in the presence of } \\
\text { high humidity in the } \\
\text { surrounding rock } \\
\text { environment. }\end{array}$ & $\begin{array}{l}\text { Fixed by dry deposition: } \\
\text { it comes from } \\
\text { particulate matter by } \\
\text { nucleation and even fine } \\
\text { particles. }\end{array}$ \\
\hline for the oxidat & f sulfurous acic & & & \\
\hline $\begin{array}{l}\text { Reversal reacton of } s \mathrm{t} \\
\text { Rounding out the or } \\
\text { Irreversible reaction } \\
\text { primary oxidant } \\
\mathrm{HSO}_{3}^{-}+\mathrm{H}_{2} \mathrm{O}_{2}(\mathrm{aq})+\mathrm{H} \\
\left(\mathrm{H}_{2} \mathrm{SO}_{4}\right) \mathrm{di} \\
\text { This is one o }\end{array}$ & $\begin{array}{l}\mathrm{n} \mathrm{H}^{+}(\text {cation hyd } \\
\text { nion). } \\
\text { Irogen ion and } \\
\text { resence of hydr } \\
\text { the atmosphe } \\
\mathrm{O}(\mathrm{aq})+2 \mathrm{H}^{+} \text {(ox } \\
\text { olved in water } \\
\text { to the formatio }\end{array}$ & $\begin{array}{l}{ }^{-} \text {(bisulfite } \\
+\mathrm{SO}_{3}{ }^{2-} \text {. } \\
\text { e which is a } \\
\mathrm{H}<=6 \text { : } \\
\text { strong acid } \\
\mathrm{n}^{\prime \prime} \text {. }\end{array}$ & $\begin{array}{r}\text { The gas-phase oxidatio } \\
\text { condensation of the sulf } \\
\text { reac } \\
\begin{array}{r}\mathrm{SO}_{2}(\mathrm{~g})+\mathrm{OH}(\mathrm{g}) \rightarrow \mathrm{HSO}_{3}^{-}(\mathrm{g}) \\
+\mathrm{H}_{2} \mathrm{O}(\mathrm{g})-\end{array} \\
\text { When the sulfuric acid cc } \\
\text { (irreversible reaction) } \\
\text { dissociation occurs ge }\end{array}$ & $\begin{array}{l}\text { f } \mathrm{SO}_{2} \text { and subsequent } \\
\text { ic acid is initiated by the } \\
\text { on : } \\
\mathrm{O}_{2}(\mathrm{~g})+\mathrm{HO}_{2}{ }^{-}(\mathrm{g}) \rightarrow \mathrm{SO}_{3}(\mathrm{~g}) \\
\mathrm{H}_{2} \mathrm{SO}_{4}(\mathrm{~g}) \\
\text { denses in the gas phase } \\
\text { to the aqueous phase } \\
\text { erating a strong acid. }\end{array}$ \\
\hline & & & $\begin{array}{r}\text { Dissociation generates } \\
\text { increasing th } \\
\mathrm{H}_{2} \mathrm{SO}_{4}(\mathrm{~g}) \rightarrow \mathrm{H}_{2} \mathrm{SO}_{4}(\mathrm{~g}) \leftrightarrow\end{array}$ & $\begin{array}{l}\text { vo protons } \mathrm{H}^{+} \text {, further } \\
\text { ocal acidity. } \\
+\mathrm{HSO}_{4}^{-} \leftrightarrow 2 \mathrm{H}^{+}+\mathrm{SO}_{4}^{2-}\end{array}$ \\
\hline & & & & \\
\hline & & $\begin{array}{r}\text { The water } \\
\text { carbona }\end{array}$ & $\begin{array}{l}\text { taining sulfuric acid covering } \\
\text { ne carbonate dissolves the } h\end{array}$ & $\begin{array}{l}\text { ne surface of the calcium } \\
\text { rogen ion by reaction: }\end{array}$ \\
\hline $\mathrm{H}_{2} \mathrm{SO}_{4}(\mathrm{aq})$ & $\begin{array}{l}\text { Aerosol acid } \\
\text { deposited in }\end{array}$ & The sulfate i & $\begin{array}{c}\mathrm{CaCO}_{3}(\mathrm{~s})+2 \mathrm{H}^{+} \leftrightarrow \mathrm{Ca}^{2+}+\mathrm{CO}_{2} \\
\text { n reacts with calcium to form } \\
\text { dihydrate : }\end{array}$ & $\begin{array}{l}+\mathrm{H}_{2} \mathrm{O}(\mathrm{aq}) \\
\text { ssociated calcium sulfate }\end{array}$ \\
\hline Aerosol st & $\begin{array}{l}\text { the stone } \\
\text { material }\end{array}$ & Calcium s & $\begin{aligned} \mathrm{Ca}^{2+}+\mathrm{SO}_{4}^{-2}+\mathrm{H}_{2} \mathrm{O}(\mathrm{aq}) \leftrightarrow \mathrm{Ca} \\
\text { Ifate dihydrate - carried by rai }\end{aligned}$ & $\begin{array}{l}\mathrm{O}_{4} \cdot 2 \mathrm{H}_{2} \mathrm{O}(\mathrm{s}) \\
\text { vater in rocks with low }\end{array}$ \\
\hline & & porosity & $\begin{array}{l}\text { dcasting services within the } \\
\text { s, predominates in rocks wi }\end{array}$ & $\begin{array}{l}\text { ck and crystallization in } \\
\text { high porosity. }\end{array}$ \\
\hline
\end{tabular}

Figure 1: Chemical reactions involving sulphur dioxide (amended from Mendonça [29]). 
The synthesis of dinitrogen pentoxide $\mathrm{N}_{2} \mathrm{O}_{5}(\mathrm{aq})$ is performed in the atmosphere from $\mathrm{NO}_{2}$ with ozone $-\mathrm{O}_{3}$ to $\mathrm{NO}_{3}$ radicals. $\mathrm{NO}_{2}$ can then be reacted with dinitrogen pentoxide obtaining $\mathrm{O}_{3} \rightarrow \mathrm{NO}_{2}+\mathrm{NO}_{3}$ and $\mathrm{NO}_{2}+\mathrm{NO}_{3} \rightarrow \mathrm{N}_{2} \mathrm{O}_{5}$. The potential of $\mathrm{NO}_{3}$ and $\mathrm{N}_{2} \mathrm{O}_{5}$ exist in the atmosphere (Kamens et al. [30]) will therefore be dependent on the simultaneous presence of $\mathrm{NO}_{2}$, and $\mathrm{O}_{3}$ and the absence of nitric oxide and sunlight, which will occur if the decomposition of $\mathrm{NO}_{3}$ : $\mathrm{NO}_{3}+$ sunlight $\rightarrow \mathrm{NO}_{2}+\mathrm{O}+$ and $\mathrm{NO}_{3}$ sunlight $\rightarrow \mathrm{NO}+\mathrm{O}_{2}$. These conditions may potentially occur overnight in rural and urban environments to obtain $\mathrm{N}_{2} \mathrm{O}_{5}$ and thus the synthesis (nitric acid) $\mathrm{HNO}_{3}(\mathrm{aq})$ to contact the rock calcium carbonate $\left(\mathrm{CaCO}_{3}\right)$ form $\mathrm{Ca}\left(\mathrm{NO}_{3}\right)_{2}(\mathrm{aq})$ - calcium nitrate - Nitrocalcite (carbonated mineral) that is calcium nitrate hydrate that is formed as an efflorescence (loss of water) in a dry environment. Fig. 2 shows, in summary, possible chemical reactions involving nitrogen dioxide and stone materials.

\begin{tabular}{|c|c|c|c|}
\hline \multicolumn{2}{|c|}{ Daytime reaction in the atmosphere of $\mathrm{NO}_{2}(\mathrm{~g})$ in the gas phase. } & \multicolumn{2}{|c|}{ Night reaction in the atmosphere of $\mathrm{NO}_{2}(\mathrm{~g})$ in the gas phase. } \\
\hline \multicolumn{2}{|c|}{7} & \multirow{5}{*}{\multicolumn{2}{|c|}{ 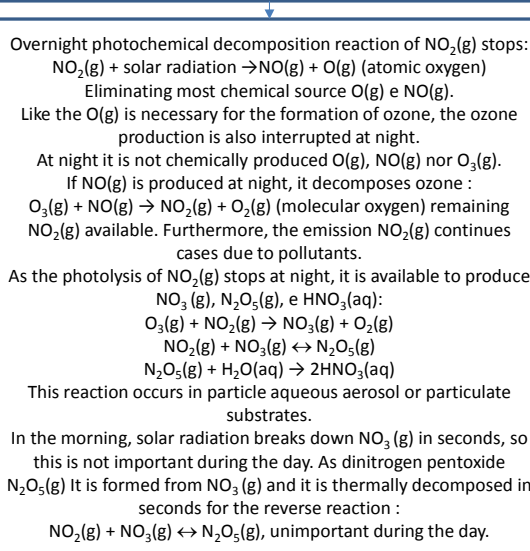 }} \\
\hline \multicolumn{2}{|c|}{$\begin{array}{l}\mathrm{NO}_{2}(\mathrm{~g}) \text { is removed from the atmosphere in irreversible reaction, } \\
\text { slow, requires the presence of hydroxyl radical : } \\
\qquad \mathrm{NO}_{2}(\mathrm{~g})+\mathrm{OH}(\mathrm{g}) \rightarrow \mathrm{HNO}_{3}(\mathrm{~g}) \text {. } \\
\text { It occurs nitric acid formation with a life span of } 15 \text { to } 80 \text { days } \\
\text { depending on the day of year and latitude. } \\
\text { The presence of hydroxyl radical is decisive for the reaction. } \\
\text { The primary source of radicals } \mathrm{OH} \text { são o } \mathrm{O}_{3}(\mathrm{~g}) \text {, solar radiation and } \\
\mathrm{H} \mathrm{O}(\mathrm{g}) \text {. } \mathrm{HNO}_{3}(\mathrm{~g}) \text { It is soluble in droplets in clouds and aerosol } \\
\text { particles before the photolysis to decompose } \mathrm{NO}_{2}(\mathrm{~g}) \text {. } \\
\text { Because the aerosol particles contained in the atmosphere } \\
\text { generally does not contain nitric acid dissociated, this enters the } \\
\text { aerosol particles almost exclusively from the gas phase, } \mathrm{HNO}_{3}(\mathrm{~g}) \text {. }\end{array}$} & & \\
\hline & & & \\
\hline $\begin{array}{l}\text { When nitric acid particles } \\
\text { dissolves in water containing } \\
\text { the reversible reaction occurs: } \\
\mathrm{HNO}_{3}(\mathrm{~g}) \leftrightarrow \mathrm{HNO}_{3}(\mathrm{aq}) \leftrightarrow \mathrm{H}^{+}+ \\
\qquad \mathrm{NO}_{3}{ }^{-} \\
\text {Forming the hydrogen ion and } \\
\text { the nitrate ion. }\end{array}$ & $\begin{array}{l}\text { When nitric acid particles } \\
\text { dissolves in water containing } \\
\text { the reversible reaction } \\
\text { occurs: } \\
\mathrm{HNO}_{3}(\mathrm{aq}) \leftrightarrow \mathrm{H}^{+}+\mathrm{NO}_{3}{ }^{-} \\
\text {Forming the hydrogen ion } \\
\text { and the nitrate ion. }\end{array}$ & & \\
\hline & & & \\
\hline $\begin{array}{l}\text { The dissociated nitric acid forms } \\
\text { a strong acid. }\end{array}$ & & $\begin{array}{l}2 \mathrm{HNO}_{3}(\mathrm{~g}) \\
\text { ocess occu }\end{array}$ & $\begin{array}{l}+\mathrm{CO}_{2}(\mathrm{~g}) \uparrow+4 \mathrm{H}_{2} \mathrm{O}(\mathrm{aq}) \\
\text { ence magnesite } \mathrm{MgCO}_{3}(\mathrm{~s})\end{array}$ \\
\hline nitrate ion are able to react with & ₹ & & 7 \\
\hline $\begin{array}{l}\text { the calcium carbonate rocks } \\
\text { presence of water in this } \\
\text { process is called acidification } \\
\text { substrate particles. }\end{array}$ & $\begin{array}{r}\mathrm{Ca}\left(\mathrm{NO}_{3}\right) \\
\text { Calcium } \\
\text { Removed the 'risir }\end{array}$ & the stone. & $\begin{array}{l}\mathrm{Ca}\left(\mathrm{NO}_{3}\right)_{2}(\mathrm{aq}) \text { Calcium nitrate or } \\
\text { nitrocalcite. Is formed as an efflorescence } \\
\text { (loss of water) in a dry environment. } \\
\text { Penetrates the pores. }\end{array}$ \\
\hline
\end{tabular}

Figure 2: Chemical reactions involving nitrogen dioxide and calcium carbonate (amended from Haneef et al. [31]).

In order to understand the formation of black crusts present in carbonate rocks one should conduct research to determine which phenomena are involved in rock interface and atmosphere, especially the water steam condensation phenomenon on the rocks and the formation of carbon film bearing metals such as $\mathrm{V}, \mathrm{Pb}, \mathrm{Ni}$, $\mathrm{Cu}$ or $\mathrm{Zn}$ as the source of emission of pollutants. Tucker [32] knows, for example, coal boilers emit $\mathrm{Ar}, \mathrm{Cr}, \mathrm{Hg}, \mathrm{Mn}, \mathrm{Ni}, \mathrm{Pb}, \mathrm{Sb}, \mathrm{Se}, \mathrm{V}, \mathrm{Cl}$, and $\mathrm{PM}$ precursors ( $\mathrm{SOx}$, NOx), but the total emission is unknown, as well as the combustion of crude oil 
emits $\mathrm{Cr}, \mathrm{Fe}, \mathrm{Ni}, \mathrm{Pb}, \mathrm{V}, \mathrm{Cl}, \mathrm{PM}$ precursors ( $\mathrm{SOx}, \mathrm{NOx}$ ), finally waste incineration emits $\mathrm{Be}, \mathrm{Cr}, \mathrm{Cd}, \mathrm{Hg}, \mathrm{Ni}, \mathrm{Pb}$, but the total is unknown. Tucker [32] shows that the effectiveness of prevention and control technologies for PM has not been well researched and documented. In Brazil, attention to this issue is not observed, which makes the research of metals present in environments - where the historical heritage made up of stones is inserted - rather dubious. This makes it harder to understand the elements that are present and how they act in chemical reactions causing the degradation of the heritage.

Regarding the waxes, Pan et al. [33] and Ozturk [34] do not recommend the use of waxes in the works of consolidation of heritage, which contradicts Cabrera [15], and Clifton [16]. However, the waxes are renewable and traditional coatings such as water repellents for furniture have been applied [14] but they produced bad consequences when applied to the stone material due to the difficulty to remove them from the surface when the cover is damaged. However, waxes are effective in surface consolidating. Care should be taken regarding the use of waxes in heritage works: a) the waxes should be used in a solution with solvents [35] or in the form of molten mixtures; b) whatever the application, the assets should be heated to maintain the molten wax during the impregnation process and increase the depth of penetration of the wax into the stone material, namely to keep the molten wax in contact with the surface as long as possible; c) the elevated temperature necessary to assist penetration can damage the stone material, causing, for example, fragmentation and detachment occuring in the form of stone material plates [16] and [35]; d) small objects with details such as statuary and architectural pieces may be impregnated by immersion in a molten wax bath, so that a suitable penetration can be achieved; e) when the infiltration is not full, the depth of penetration of the wax is always surficial; f) the waxes may be considered as protective coatings instead of primers; $g$ ) the waxes may cause yellowing of the treated surfaces [34]; h) the impregnated wax can rarely be removed completely [33]; i) the wax-based protection may be recommended for non-porous stone material, granite, rocks or calcareous; j) bees wax may generate composite efflorescence, mainly alkenes [36]; k) paraffin waxes are among the more durable conservation of materials and may prevent movement soluble salts [16].

\section{Acknowledgements}

We thank the Programa de Pós-graduação em Engenharia Civil from Universidade Federal Fluminense, Centro Federal de Educação Tecnológica de Minas Gerais, Coordenação de Aperfeiçoamento de Pessoal de Nível Superior - Portal de Periódicos and Fundação de Amparo a Pesquisa de Minas Gerais.

\section{References}

[1] Silva, M. E. D.; Roeser, H. M. P. Mapeamento de deteriorações em monumentos históricos de pedra-sabão em Ouro Preto. Revista Brasileira de Geociências, n. 33, pp. 331-338, dezembro 2003. 
[2] Bibliograf. Lexis 22: Diccionario Enciclopédico Vox Mineralogía, Geología. Barcelona: Círculo de Lectores, 1981. 287 p. ISBN 842261247X 9788422612476.

[3] Popp, J. H. Geologia Geral. 6a . ed. Rio de Janeiro: LTC - Livros Técnicos e Científicos Ltda., 2012. 309 p. ISBN 978-85-216-1760-0.

[4] Machado, F. B. et al. Banco de Dados - Museu Heinz Ebert. Enciclopédia Multimidia de Minerais e Atlas e Rochas, Rio Claro, www.rc.unesp.br/ museudpm/banco/index.html.

[5] Steiger, M.; Charola, A. E. Weathering and Deterioration. In: Siesgemund, S.; Snethlage, R. Stone in Architecture. Berlin: Springer, 2011. pp. 227-316.

[6] Pidwirny, M. Weathering. E-Book - Fundamentals of Physical Geography, Vancouver, www.physicalgeography.net/ fundamentals/10r.html.

[7] United States Environmental Protection Agency (USEPA). Six Common Air Pollutants, www.epa.gov/airquality/urbanair.

[8] CETESB. Qualidade do ar no Estado de São Paulo. Companhia de Tecnologia de Saneamento Básico e de Defesa do Meio Ambiente do Estado de São Paulo. São Paulo, p. 234. 2011.

[9] Sharma, R. K.; Gupta, H. O. Dust pollution at the Taj Mahal: a case study. Conservation of stone and other materials - RILEM proceedings: 21. Paris: E. \& F.N. Spon. 1993. pp. 11-18.

[10] BRASIL. Resolução CONAMA (Conselho Nacional de Meio Ambiente) $\mathrm{n}^{\mathrm{o}}$ 03. CONAMA. Brasília. 1990.

[11] Doehne, E.; Clifford, A.; Ferguson, P. Stone conservation an overview of current research. $2^{\mathrm{a}}$ ed. [S.1.]: [s.n.], 2010. 175 p.

[12] U.K. PORG. Ozone in the United Kingdom. Department of the Environment, Transport and the Regions. London. 1997. (ISBN: 0-87039330-9).

[13] Mangio, R.; Johansson, L. G. The influence of ozone on the atmospheric corrosion of Carrara marble in humid atmospheres containing sulphur dioxide; deposition studies of $\mathrm{SO}_{2}$ on marble. 11th Scandinavian Corrosion Congress: NKM 11: Proceedings, Ullandhaug, Stavanger, June 19-21. Stavanger: Centrum Trykkeri A.S. 1989.

[14] Horie, V. Materials for Conservation - Organic consolidants, adhesives and coatings. $2^{\mathrm{a}}$ ed. Oxford: Elsevier Ltd., v. I, 2010.

[15] Cabrera, J. M. Cursos Monográficos sobre el Patrimonio Histórico. Actas de los VIII Cursos Monográficos sobre el Patrimonio Histórico. España: Universidad de Cantabria, Servicio de Publicaciones. 1998. p. 495.

[16] Clifton, J. R. Stone Consolidating Materials - A Status Report. 1 a . ed. [S.1.]: Foundation of the American Institute for Conservation of Historic and Artistic Works (FAIC)-Conservation OnLine (CoOL), v. I, 2008.

[17] White, R. The Application of Gas-Chromatography to the Identification of Waxes. Studies in Conservation, v. 23, n. 2, pp. 57-68, May 1978. ISSN 00393630.

[18] ASTM. ASTM E2167-01 (Reapproved 2008) - Standard Guide for Selection and Use of Stone Consolidants. American Society for Testing and Materials. West Conshohocken, USA, p. 7. 2008. 
[19] ASTM. ASTM E632-82(1996) - Standard Practice for Developing Accelerated Tests to Aid Prediction of the Service Life of Building Components and Materials (Withdrawn 2005) - Esta norma foi descontinua pela ASTM. American Society for Testing and Materials. West Conshohocken, USA, p. 6. 1996.

[20] Munnikendam, R. A. A New System for the Consolidation of Fragile Stone. Studies in Conservation, v. 118, n. 2, pp. 95-97, May 1973. ISSN 00393630.

[21] ASTM. ASTM C97/C97M-09 - Standard Test Methods for Absorption and Bulk Specific Gravity of Dimension Stone. American Society for Testing and Materials. West Conshohocken, USA, p. 3. 1979.

[22] National Materials Advisory Board. Conservation of Historic Stone Buildings and Monuments. $1^{\mathrm{a}}$. ed. Washington, DC: National Academy Press, v. I, 1982. 379 p. Committee on Conservation of Historic Stone Buildings and Monuments, National Materials Advisory Board, National Research Council, Commission on Engineering and Technical Systems, Division on Engineering and Physical Sciences.

[23] ASTM. ASTM E96/E96M-13 - Standard Test Methods for Water Vapor Transmission of Materials. American Society for Testing and Materials. West Conshohocken, USA, p. 13. 1995.

[24] ASTM. ASTM D1535-13 - Standard Practice for Specifying Color by the Munsell System. American Society for Testing and Materials. West Conshohocken, USA, p. 41. 2013.

[25] ASTM. ASTM D1729-96 (Reapproved 2009) - Standard Practice for Visual Appraisal of Colors and Color Differences of Diffusely-Illuminated Opaque Materials. American Society for Testing and Materials. West Conshohocken, p. 4. 2013.

[26] ASTM. ASTM E2466-13 - Standard Test Method for Colorimetry of Teeth Using Digital Still Camera Technology. American Society for Testing and Materials. West Conshohocken, USA, p. 13. 2013.

[27] ASTM. ASTM D523-08 - Standard Test Method for Specular Gloss. American Society for Testing and Materials. West Conshohocken, USA, p. 5.2008.

[28] Barros, A. Os monumentos e as doenças de pedra. Colóquio Ciências, Lisboa, n. 9, pp. 59-74, 1991. ISSN 0870-7650.

[29] Mendonça, M. Curso de degradação do patrimônio histórico. Bahia. 2004.

[30] Kamens, M. R. et al. Polynuclear aromatic hydrocarbon degradation by heterogeneous reactions with $\mathrm{N}_{2} \mathrm{O}_{5}$ on atmospheric particles. Atmospheric Environmental, 24, n. 5, 1990. 1161-1173.

[31] Haneef, S. J. et al. Effect of dry deposition of $\mathrm{NOx}$ and $\mathrm{SO}_{2}$ gaseous pollutants on the degradation of calcareous building stones. Atmospheric Environment, v. 26A, n. 16, pp. 2963-2974, 1992.

[32] Tucker, W. G. An overview of PM 2.5 sources and control strategies. Fuel Processing Technology, 65-66, Junho 2000. 379-392.

[33] Pan, A. et al. Excimer laser removal of beeswax from Galician granite monuments. Journal of Cultural Heritage, v. 10, pp. 48-52, April 2009. ISSN 1296-2074. 
648 Sustainable Development, Vol. 1

[34] Ozturk, I. Alkoxysilanes consolidation of stone and earthen building materials. $1^{\text {a }}$. ed. Pennsylvania: University of Pennsylvania, v. I, 1992.

[35] Laurie, A. P.; Ranken, C. The Preservation of Decaying Stone. Journal of the Society of the Chemical Industry, Edinburgh, v. 37, pp. 137T-147T, December 1917.

[36] Bartl, B. et al. Analysis of efflorescence on surface of beeswax seals. Journal of Cultural Heritage, v. 13, n. 3, pp. 275-284, December 2012. ISSN 1296-2074. 